безопасности, определенные Конституцией Российской Федерации и законодательством РФ, в том числе транспортную безопасность.

В современном обществе транспорт включен в различные сферы жизнедеятельности государства и общества. Укрепление режима безопасного функционирования, повышения антитеррористической защищенности объектов транспортной инфраструктуры, а также их совершенствование и развитие отнесены Стратегией к мерам, обеспечивающим государственную и общественную безопасность, повышение качества жизни, экономический рост.

Стратегия национальной безопасности является базовым документом стратегического планирования, определяющим интересы и приоритеты нашей страны, цели и задачи внутренней и внешней политики, направленные на укрепление национальной безопасности и обеспечение устойчивого развития на долгосрочную перспективу. [9]

$$
* * *
$$

1. Форзун Е. А. Проблемные вопросы стратегического планирования развития региона // Научнометодический электронный журнал «Концепт». - 2015. - Т. 14. - С. 31-35 режим доступа: http://ekoncept.ru/2015/95138.htm.;

2. Магданов П.В. Современная парадигма стратегического планирования // ARS ADMINISTRANDI 2014. №1. - режим доступа: http://cyberleninka.ru/article/n/sovremennaya-paradigma-strategicheskogoplanirovaniya.;

3. Чмышенко Е.Г., Чмышенко Е.В.Определение объектов регионального стратегического планирования // Вестник ОГУ. - 2014. №1. - режим доступа: http:// cyberleninka.ru /article/n/opredelenie-obektov-regionalnogo-strategicheskogo-planirovaniya;

4. Письмо ФНС России от 12.05.17 № АС-4-2/8872;

5. Приказ ФНС России от 30.05.2007 N MМ-3-06/333@;

6. Федеральный закон "О противодействии коррупции" от 25.12.2008 N 273-Ф3;

7. Федеральный закон "О противодействии легализации (отмыванию) доходов, полученных преступным путем, и финансированию терроризма" от 07.08.2001 N 115-Ф3;

8. Указ Президента РФ от 31.12.2015 N 683 "О Стратегии национальной безопасности Российской Федерации";

9. Трофимов Д.А. Транспортная безопасность в системе национальной безопасности // Труды Академии управления МВД России. 2016. № 3 (39).

\title{
Земскова Т.И. \\ Анализ динамики предоставления кредитов субъектам МСБ Магаданским филиалом ПАО банк «Возрождение» за последние 5 лет
}

Северо-Восточный государственный университет (Россия, Магадан)

doi:10.18411/spc-22-01-2018-21

idsp: 000001:spc-22-01-2018-21

Научный руководитель: Акулич О.В.

В современных условиях в России малый и средний бизнес является важным инструментом для решения комплекса экономических, политических и социальных проблем, стоящих перед государством. Успешное и эффективное развитие МСП в значительной степени зависит от обеспеченности предпринимателей финансовыми ресурсами как долгосрочного, так и краткосрочного характера.

Субъекты малого и среднего бизнеса нуждаются в источниках финансирования как на стадии становления, так и в процессе развития. Наиболее востребованными источниками финансирования для этих субъектов бизнеса становятся банковские кредиты и финансовые субсидии государства. 
Предприятия малого и среднего бизнеса исторически составляют ключевой клиентский сегмент Банка «Возрождение», кредитование малого бизнеса является приоритетным направлением клиентской политики банка.

Данная статья посвящена динамическому анализу предоставления кредитов МСБ Магаданским филиалом ПАО Банк «Возрождение» за 2012-2016 гг.

В таблице 1 представлены данные по предоставленным кредитам за период 2012-2016гг.

Таблиия 1

Объем предоставленных кредитов субъектам МСБ за 2012-2016гг., в млн. руб.

\begin{tabular}{|c|c|}
\hline Год & Сумма, в млн.руб. \\
\hline 2012 г. & 1000 \\
\hline 2013 г. & 691,4 \\
\hline 2014 г. & 802,41 \\
\hline 2015 г. & 1906,72 \\
\hline 2016 г. & 1370,88 \\
\hline
\end{tabular}

Динамика предоставления кредитов субъектам МСБ ПАО Банк «Возрождение» за последние 5 лет представлена на рисунке 1.

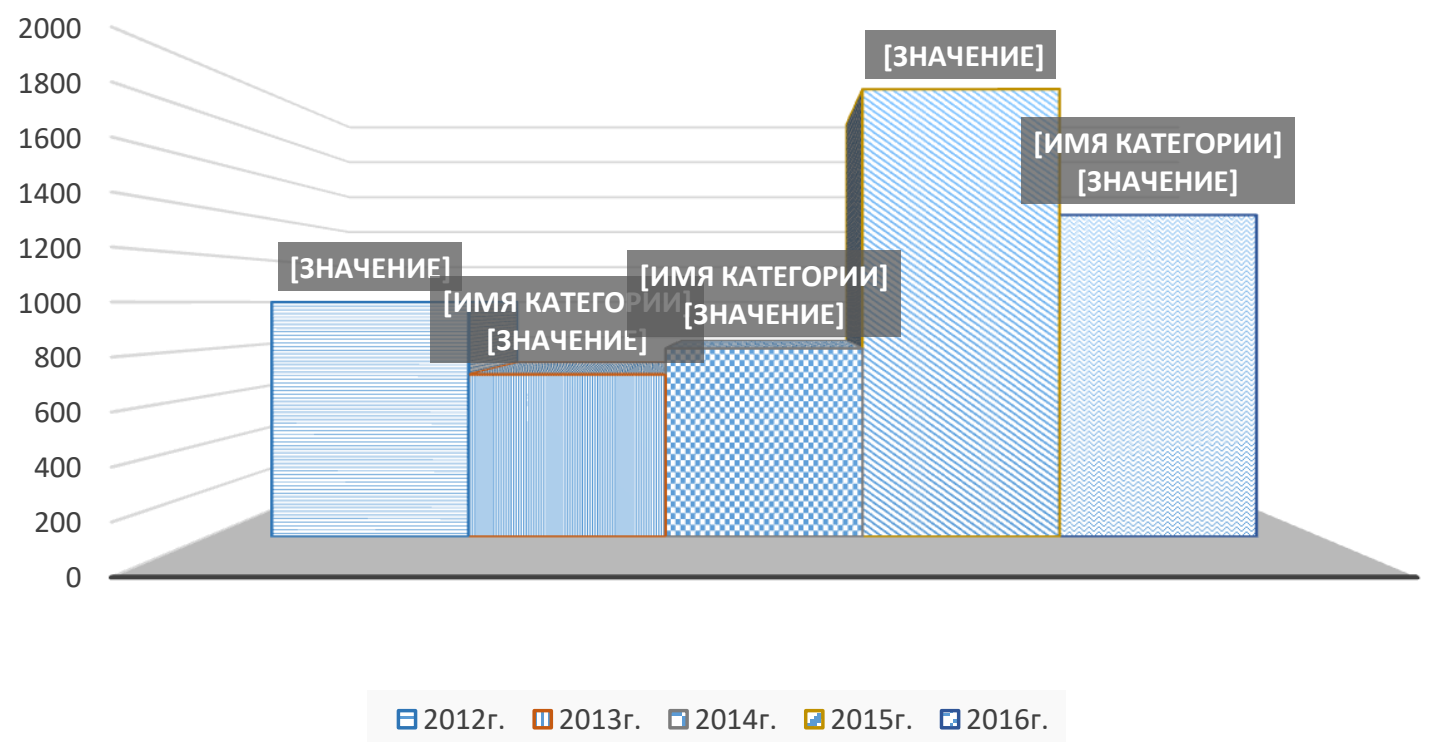

Рис. 1. Динамика предоставления кредитов субъектам МСБ ПАО Банк «Возрождение» за последние 5 лет, в млн руб.

Анализируя данный график, можно сделать выводы, что объемы выданных кредитов МСБ, за определенный период выросли. Так, по состоянию 2016 г. было выдано 1370,88 млн. руб. Это на 37,09\% больше, чем в 2012 г. А именно, общий прирост за 2012-2016 гг. составил 370,88 млн. руб. При этом необходимо отметить, что этот прирост носил неравномерный характер. Данный объем снизился по сравнению с 2015 г. на 28,1\% или 535,84 млн.руб. Это говорит о том, что темпы кредитования замедляются. Причиной этому может служить снижение спроса на кредитные ресурсы со стороны малого и среднего бизнеса вследствие роста стоимости кредитов, ужесточение требований к заемщикам: сказались повышение ключевой ставки.

По состоянию на 2015 год было выдано кредитов МСБ на сумму 1906,2 млн. руб. Так, прирост за 2015 г. по отношению к 2014 г. объемов выданных кредитов МСБ составил 1104,31 млн.руб. или 137,62\%. Причиной может служить наблюдаемый рост портфеля МСБ. 
В 2014 г. объем выданных кредитов МСБ составил 802,41 млн. руб., увеличение составило 111,01 млн. руб. или 16,06\% по сравнению с 2013 г. А в 2013 г. объем кредитов, выданных МСБ, составил 691,4 млн. руб., снижение составило почти на 31 \% (308,6 млн. руб.) по сравнению с 2012 г. За весь период 2012-2016 гг. 2013-2014гг. показали самый низкий объем выданных кредитов МСБ.

Причиной стал фактор самого заемщика, поскольку малые и средние компании сталкивались с замедлением или остановкой роста. Т.е. снижение объёмов кредитов, в первую очередь, связано с ухудшением финансового состояния и снижением уровня платёжной дисциплины заёмщиков, что обусловило ужесточение требований банков к ним.

В 2013 году на темпы роста кредитования МСБ оказали давление торможение потребительского спроса и спад инвестиционной активности, а также рост оборачиваемости «кредитных фабрик» крупных банков и, как следствие, уменьшение их вклада в рост портфеля МСБ. Важную роль сыграли и негативные ожидания предпринимателей, которые не нацелены на расширение бизнеса в условиях нестабильности экономики.

Для рынка кредитования МСП в 2014 год оказался весьма непростым: все основные показатели продемонстрировали отрицательную динамику - снизился объем выданных кредитов, сжался кредитный портфель, увеличился объем просроченной задолженности и ее доля в портфеле. Основных причин несколько - это, в первую очередь, ухудшение экономического положения самих субъектов МСП, которое негативно повлияло на их платежную дисциплину. Банки в условиях замедления экономики и нестабильной ситуации в финансовом секторе страны направили свои усилия на снижение рисковой составляющей в своих активах, и в первую очередь это коснулось кредитования субъектов МСП - традиционно одного из наиболее нестабильных сегментов банковского рынка. Кредитные организации на протяжении первых трех кварталов 2014 года постепенно ужесточали требования к обеспечению и финансовому положению заемщиков, сокращали спектр направлений кредитования и уменьшали количественные параметры сделок с МСП.

Динамика рынка кредитования МСБ в 2017 г. определена снижением покупательной активности населения, ухудшением финансового положения бизнеса (a, следовательно, и снижением числа качественных заемщиков), сохранением жестких требований банков. Скорость восстановления рынка в существенной мере определена мерами господдержки МСБ. В 2017 г. перед банками особенно остро стоит вопрос баланса между доходностью и уровнем принимаемого риска. С учетов ожидаемого ухудшения финансовых показателей малых и средних предприятий в приоритете у банков остается качество портфелей.

Среди других направлений развития МСБ можно отметить расширение доступа малым и средним предпринимателям к госзаказу, а также формирование для крупных корпораций системы поставщиков и подрядчиков из субъектов МСБ. Это позволит МСБ найти рынки сбыта, что позитивно отразится на их финансовых показателях. В случае реализации основных задач, стоящих перед Федеральной корпорацией МСП, ожидается восстановление рынка до докризисного уровня, однако не раньше, чем в 2018 г.

$$
\text { *** }
$$

1. Гиблова Н. М. Как помочь малому и среднему бизнесу? / Банковское кредитование. 2014. - № 3. $156 \mathrm{c}$.

2. Кртян А. С. Проблемы кредитования малого и среднего бизнеса / Молодой ученый. 2014. - № 6.$160 \mathrm{c}$. 